\title{
OECD DAC 통계작업반 워크샵 결과
}

OECD 개발원조위원회(DAC) 산하 표제회의가 2009.12.2-4간 오스트리아 비엔나 외교부에서 개최되었다. 본 회의에서는 원조전달채널(channel of delivery) 정의 및 개정, 유엔평화유지활동 (UNDPKO) 및 유엔 이외 국제평화유지활동의 ODA 보고 방안, 신규원조유형(new typology of aid) 보고 및 관련 통계작성지침 개정에 대한 향후 일정, ODA Plus, 원조투명성 및 예측가능성, 기후변 화 완화 및 적응 보고 방안 등이 논의되었다. 동 회의에는 외교부, KOICA 및 한국수출입은행으로 구성된 대표단이 참석하여 아래와 같이 주요 회의 내용을 정리, 보고하였다.

\section{I. 논의내용}

\section{1. 원조전달채널(channel of delivery) 정의}

$\mathrm{DAC} 1$ table 개정양식에 주요 핵심항목(key DAC statistical concept)으로서 원조전달채널 포 함 관련, 국가수준에서 프로그램 집행을 분석하는 시초(starting point for analysing project implementation arrangement at the country level)로서 활용도를 감안하여 반드시 포함되어야 한다는 회원국의 공감대가 형성됨.

다자기구 및 $\mathrm{NGO}$ 를 전달채널로 하는 원조와 관련하여 증가하는 정보공개 요구에 대한 투명성 확 보, 파리선언 및 아크라행동계획 이행 모니터링 차원에서 수원국의 주인의식 및 상호책무성 강화, 원조분절성 이슈 관련 정책 분석자료로 활용성 등 원조전달채널이 중요성을 확인함. 회원국들은 사무국이 제안한 정의에 큰 이견은 없으나 신규로 정의를 내린 '기타(Other, 50000)' 항목의 일부 집행주체(예: individual consultant, research institute 등)에 대한 정의가 불분명 하다는 의견을 제시하였고, 이에 사무국은 보완 설명을 첨가하기로 함.

\section{2. 원조전달채널 세분화 논의}


공공부문(Public sector, 10000)을 공여국정부(11000), 수원국정부(12000), 제3국정부 (Delegated co-operation, 13000)로 세분화 하는 것에 대해 논의함. 미국은 연구기관이 '기타 (Other, 50000)' 항목으로 분류되는 것과 관련, 국책 연구기관은 예외적으로 '공공부문'으로 분류 해야 한다고 제안하였고, 캐나다, 독일, 노르웨이 등이 동의함.

3개의 하위범주에 속하지 않는 경우(삼각협력(triangular cooperation), 협조융자(cofinancing), 공동집행(joint implementation) 등) 채널 지정에 대한 문제점이 제기된 바, 사무국은 향후 회원국 의 추가 검토의견을 수렴하여 보완하겠다고 답변함.

$\mathrm{NGO}$ 및 시민사회(20000)를 Int'l NGO(21000), National NGO(22000), 개도국 기반 $\mathrm{NGO}$ (23000)로 세분화 하는 것에 대해 논의함. 한국, 노르웨이 등은 $\mathrm{NGO}$ 구분기준으로 자금 출 처만 고려하는 것은 불충분하다고 지적하였고, 이에 사무국은 본부 소재지, $\mathrm{NGO}$ 들이 스스로 규정 하는 identity 등 다른 기준들도 검토하여 통계작성지침에 반영될 수 있도록 노력하겠다고 함. 스웨 덴, 독일, 스위스 등은 자국 $\mathrm{NGO}$ 에 지원한 자금이 다시 개도국 $\mathrm{NGO}$ 의 집행자금으로 사용될 경우 집행주체 구분에 대한 정보제공의 필요성을 제기하였고, 사무국은 간결한 정보수집을 위해 1 차 수 혜 $\mathrm{NGO}$ 가 지정되어야 한다고 답변함.

사무국은 annex2에 등재되지 않으나 양자 earmark된 ODA 계상 가능한 다자기구 지원의 경우 데 이터 품질 관리를 위해 신규코드(Agencies not on Annex2, 48000)를 추가할 것을 제안함. 한편 독일은 UN과 non-UN 2개 카테고리로 분류하자는 안을, 오스트리아는 현 카테고리 유지가 바람 직하다는 의견을 제시함. 이에 사무국은 2010년 6월 통계작업반 공식회의에서 상기 3가지 안에 대 해 논의키로 함.

기타(Other, 50000) 항목의 구체적인 정보수집을 위해 분류를 세분화한 사무국의 제안에 대해 회 원국들은 민간기업에 대한 세부항목 추가 및 연구기관과 대학 항목간의 명확한 구분의 필요성을 제 기함.

\section{3. 다자기구 카테고리 변경에 따른 기존 데이터 관리}

사무국은 다자기구의 카테고리 변경시 신규 코드 부여 여부와 신규 코드 부여시 기존 데이터 관리 방안에 대해 2 가지를 안을 제시함. 1 안은 기존 코드를 유지하면서 신규 코드 부여, 2 안은 기존 코 드를 유지하면서 카테고리만 변경하는 내용임. 


\section{UNDPKO 등 국제평화유지활동의 ODA 계상 문제}

UNDPKO 평화활동유지 지원 보고시 개별 미션별(mission by mission) 보고의 의무화 제안과 관 련, 미국, 오스트리아, 캐나다 등은 개별 사업에 대한 구체적 정보 제공을 통한 투명성 제고 차원에 서 찬성 의사를 표명함.

$\mathrm{UN}$ 이외 다른 국제 평화유지활동 관련, 사무국측 purpose code(15220, 15230) 개정안의 포함범 위(coverage)는 양자만 포함됨. 그러나 현재 일부 회원국은 다자지원도 purpose code를 보고하는 경우가 있으므로 향후 추가적으로 논의를 진행하기로 함.

\section{5. 신규 원조유형(new typology of aid)}

사무국은 2011년 보고(2010년 실적)시부터 적용될 신규 원조유형에 따른 DAC table 개정안 관련 향후 일정을 공지함.

- 2009.12 : 2002년 이후 회원국별 실적에 대한 새로운 DAC1 테이블 생성

- 2010.01-02 : 회원국의 DAC1 테이블 검증 및 피드백 사무국 제출

- $2010.04: 1960-2001$ 년 실적에 대한 새로운 DAC1 테이블 작성

아울러, 신규 원조유형을 반영하는 통계작성지침안 개정 일정을 아래와 같이 공지함.

- 2010.01-02 : 사무국의 통계작성지침안 초안 작성(2010.06월 승인 목표)

- 2010.09 : 사무국의 CRS++ 가이드라인 업데이트(2010-11 : 검증)

- 2010.07 : CRS 통계와 DAC 통계 통합 작업 시작(2012.06월 승인 목표)

$\rightarrow$ 2012년부터 완전한 통합 보고 가능 목표(11년 실적)

\section{6. 기타공적자금(OOF) 및 민간흐름(Private flow)}

회원국들은 ODA Plus 개념 도입이 현 ODA 정의 수정, 범위 확대, 질 개선 차원에서 논의되어서는 안된다는 것을 강조하고, non-ODA 자금과 개발협력과의 연관성 및 ODA와의 상호보완성에 대한 면밀한 분석 선행의 필요성에 대한 인식을 같이함. 현재 IMF, WB 등 다른 금융기관에서 기수집하 고 있는 통계를 활용함으로써 업무중복 및 추가 업무부담을 경감하는 방안을 도모할 필요성이 제기 됨. 


\section{7. 원조투명성 및 예측가능성}

지난 5 월 60 차 통계작업반 회의시 회원국들은 통계작업반 사무국이 원조효과작업반(WP-EFF) 클 러스터 $\mathrm{C}$ (원조투명성 및 예측가능성)와 국제 원조투명성 제고 이니셔티브(IATI)가 원활하게 공조할 수 있도록 지원하고, IATI의 TAG(Technical Advisory Group)에 통계관련 기술자문을 제공하기 로 합의한 바, 효율적인 작업을 위해 각 주체 간 긴밀한 공조와 상호 이해가 요구됨. 한편 금번 회 의에서 사무국은 2011년 개최예정인 제4차 서울 원조효과 고위급회의(HLF-4)까지 원조투명성 제 고 성과가 진전될 수 있도록 노력하는 것이 특히 중요하다고 강조함.

사무국은 통계작업반이 원조효과성 제고에 기여하기 위한 방안으로 IATI와 공조시 3가지 부문에 대한 논의가 필요하다고 소개함. 첫째, 수원국 중기전략 수립 및 이행을 모니터링하기 위한 통계 활 용의 중요성, 둘째, IATI 이행을 위한 메커니즘, 셋째, 활용할 데이터의 선별임. 이와 관련, 사무국 은 논의진전을 위해 2010년 6월 회의시 IATI TAG가 상기 관련 안건을 준비할 것을 제안함.

\section{8. 기후변화 완화 및 적응 보고 방안}

사무국은 수원국에서 진행되는 기후변화 관련사업은 개발 효과에 대한 검증없이 ODA로 보고되는 경향이 있고, 수혜 혜택이 공여국으로 돌아가는 경우가 있다며, 기후변화 관련사업의 ODA 적격성 판단 기준에 대한 명확한 정의규정의 필요성을 제기함. 이에, 2010년 2월 개최 예정인 DAC 통계 작업반-환경네트워크 합동회의(WP-STAT/ENVIRONET)시, ODA 보고가능한 기후변화 적응 사 업의 범주와 $\mathrm{CRS}$ 통계보고 방식에 대해 논의할 예정임. 아울러, 동 회의에서는 현재까지 리우마커 로 보고된 사업의 데이터 품질 모니터링과 보고 개선방안에 대해서도 논의할 예정임.

\section{II. 기타 사항}

금번 회의 공식 시작에 앞서, Ms. Hedwig Riegler DAC 통계작업반 의장(오스트리아)은 한국의 $\mathrm{DAC}$ 가입을 소개하며 축하의사를 전하였으며, 이에 대표단은 사의를 표명함. DAC 가입 이후, 회원 국으로서 통계 보고 내용이 증대되고 작업반 활동에 정례참여 필요성을 감안, 통계작업반 관련 회 의에 본부 및 관계기관의 전문가를 대표로 참석시켜 주실 것을 건의함. 특히, 비공식회의에서 공식 회의의 의제 채택이 논의되는 등 회원국으로서 우리의 입장이 의제에 반영될 수 있도록 적극적인 참여가 요구됨. 제61차 통계작업반 회의는 2010년 6월, DAC 환경네트워크-통계작업반 합동회의 는 2010.02.22일 개최될 예정임. 


\section{III. 관찰 및 건의}

\section{DAC 통계회의 적극적 참여 중요}

통계작업반 비공식회의에서는 공식회의의 의제 채택 및 의제 내용 조정이 이루어지는 바, 신규 $\mathrm{DAC}$ 회원국으로서 논의 동향 파악 뿐 아니라 우리의 입장이 의제에 반영될 수 있도록 적극적인 참 여가 중요하며, 향후 관련 의제 개발에도 관심을 기울여야함. 아울러, 통계작업반은 ENVIRONET, $\mathrm{WP}-\mathrm{EFF}, \mathrm{GENDERNET}$ 등 타 DAC 산하작업반과의 긴밀한 공조를 통해 통계를 통한 근거 중심 (evidence-based)의 원조관행을 추구하기 위한 노력을 추진하는 바, 관련 합동회의 및 $\mathrm{TF}$ 작업에 도 활발한 참여가 중요함.

\section{KOICA 통계작성지침 준수 강화 및 질적 개선 필요}

신규 $\mathrm{DAC}$ 회원국으로서 통계관련 의무 보고 사항이 증가하고, 보고된 통계자료의 품질관리가 더 엄격해짐에 따라 $\mathrm{DAC}$ 통계작성지침 준수 강화 및 $\mathrm{KOICA} \mathrm{ODA} \mathrm{통계} \mathrm{질적} \mathrm{개선이} \mathrm{필요함.} \mathrm{특히,}$ $\mathrm{DAC}$ table1 개정, $\mathrm{ODA}$ 적격성 심사 강화, 언타이드 보고 확대, 충실한 사업설명 작성 등 투명하고 적합한 통계자료 생성 및 보고를 위한 노력을 지속적으로 경주해야 함.

\section{KOICA 통계전담 인력 확대}

$\mathrm{OECD} / \mathrm{DAC}$ 는 동료평가, 산하작업반 활동을 통한 원조효과성 제고작업과 더불어 통계를 3 대 비교 우위분야로 지정하고 산하작업반 활동에 통계활용 확대방안을 모색중임. 한편, KOICA는 2010년 사업계획추진시 통계정책마커를 활용한 정책 관리를 강화할 예정임. 따라서, 통계의 양 - 질적 개선 도모를 위해 $\mathrm{KOICA}$ 통계생성, $\mathrm{DB}$ 구축, $\mathrm{ODA}$ 통계보고 및 교육관련 담당 인력의 확대가 요구됨. 